\title{
Rapid estimation of serum cholinesterase activity using the Astrup micro equipment
}

\author{
J. K. JOHNSON AND T. P. WHITEHEAD
}

From the Department of Biochemistry, Queen Elizabeth Hospital, Birmingham

SYNOPSIS A rapid micro technique for the estimation of serum cholinesterase is described. Acetylcholine bromide is incubated with serum within the capillary of the Astrup electrode. The enzyme hydrolyses the substrate with the liberation of acetic acid. This causes a fall of $p \mathrm{H}$ which is seen on the galvanometer of the instrument and the rate of this fall is shown to be proportional to enzyme concentration.

The method has been calibrated in international units and compared with a more conventional technique. The values found in homozygotes with normal dibucaine-resistant enzymes and in heterozygotes are reported, together with their dibucaine and fluoride numbers.

Prolonged apnoea following the administration of scoline (succinyl-dicholine) in anaesthesia usually occurs in patients who are homozygous for the atypical type of serum cholinesterase (Bush, 1961). These patients all have a low concentration of the enzyme. Serum cholinesterase estimation is of most value in assessing the cause of apnoea and the result can be given within a few minutes. This method was evolved to measure rapidly and accurately the enzyme activity with the minimum delay and disruption of laboratory routine.

\section{MATERIALS AND METHOD}

REAGENT: 0.05 M. ACETYLCHOLINE BROMIDE $(1 \cdot 136 \mathrm{~g} . / 100$ $\mathrm{ml}$.) The solution was found to be stable for several months at $-20^{\circ} \mathrm{C}$. It was dispensed in $1 \mathrm{ml}$. amounts in polystyrene cups with polythene caps which had been purchased for use on the autoanalyser. The contents of one of these was thawed when required.

The solid acetylcholine bromide was kept in a desiccator over silica gel.

ASTRUP MICRO EQUIPMENT The Radiometer A.M.E. 1 apparatus was used. The $p \mathrm{H}$ meter has an extended scale between $p \mathrm{H} 6.6$ and 8.0. The electrode was standardized using a buffer of $p \mathrm{H} 7.38$ before every test and checked occasionally with a buffer of $p \mathrm{H} \mathrm{6.98}$.

The equipment includes a tonometer in which up to $0.1 \mathrm{ml}$. of solution may be equilibrated with a humidified oxygen and carbon dioxide mixture. All parts of the apparatus are surrounded by water jackets at $38^{\circ} \mathrm{C}$.

TECHNIQUE Into the tonometer of the Astrup micro Received for publication 5 February 1965. equipment $0.05 \mathrm{ml}$. of serum was introduced and equilibrated with $4 \% \mathrm{CO}_{2}, 96 \% \mathrm{O}_{2}$ mixture for two minutes.

To this was added $0.05 \mathrm{ml}$. of $0.05 \mathrm{M}$. acetylcholine bromide and the mixture shaken for 10 to 15 seconds. This mixture was sucked into the capillary of the electrode and the $p \mathrm{H}$ read. It was usually between $7 \cdot 35$ and $7 \cdot 45$ and immediately started to fall. The time (t) taken for the fall from $p \mathrm{H} \mathrm{7 \cdot 3}$ to $7 \cdot 1$ was measured in seconds. (This was normally between 30 and 65 seconds.)

CALCULATION $\frac{150}{\mathrm{t}} \times 100=$ cholinesterase activity in international units per $100 \mathrm{ml}$. serum.

NORMAL VALUES These were obtained from the sera of 25 male and 25 female, healthy blood donors. The sera were first screened by the agar diffusion technique (Harris and Robson, 1963), using R $02-0683$ as inhibitor, to exclude homozygotes or heterozygotes for the atypical (dibucxine-insensitive) enzyme. Serum from a normal male was substituted for that from the one heterozygote found in the group.

For male adults the mean is 403 i.u. per $100 \mathrm{ml}$. serum, the standard deviation is 64 i.u., and the normal range ( $95 \%$ of the population) is 274 to $532 \mathrm{i} . \mathrm{u}$. per $100 \mathrm{ml}$. serum.

For female adults the mean is 352 i.u. per $100 \mathrm{ml}$. serum, the standard deviation is $74 \mathrm{i} . \mathrm{u}$., and the normal range ( $95 \%$ of the population) is 204 to 500 i.u. per 100 ml. serum.

The significance of difference between the means for males and females was calculated and the probability $(P)$ that they were the same populations found to be between 0.01 and 0.02 . This indicated that there was a significant difference between the two normal ranges which confirm- 
ed previous findings (Rider, Hodges, Swader, and Wiggins, 1957).

PRECISION Twenty-five single determinations of the cholinesterase activity of the same serum were performed. The mean value was 238 i.u. per $100 \mathrm{ml}$. serum, the standard deviation $\pm 3.02 \mathrm{i}$. u. per $100 \mathrm{ml}$. serum, and the mean \pm 3 standard deviations $(99.6 \%$ of all determinations) \pm 9.06 i.u. per $100 \mathrm{ml}$. serum $= \pm 4 \%$.

\section{RESULTS OF TESTS PERFORMED TO DEVELOP AND INVESTIGATE THE METHOD}

THE INITIAL $p \mathrm{H}$ OF SERUM The $p \mathrm{H}$ of separated serum rises during storage due to loss of carbon dioxide. Thus, a freshly taken sample may be close to $p \mathrm{H} 7.4$ and 12 hours later have risen to $p \mathrm{H} \mathrm{8.6.}$ To bring the initial $p \mathrm{H}$ of the reaction mixture to within a reasonable range the serum was equilibrated with the $4 \% \mathrm{CO}_{2}, 96 \% \mathrm{O}_{2}$ gas mixture used in the Astrup technique for $\mathrm{CO}_{2}$ measurement. This brought the $p \mathrm{H}$ of serum with a normal standard bicarbonate to between $7 \cdot 35$ and $7 \cdot 45$.

OPTIMUM PROPORTIONS OF REACTANTS The rate of $p \mathrm{H}$ decrease at various substrate concentrations was determined using pooled serum. The resulting curves were roughly parallel using substrate concentrations above that produced by adding $0.0125 \mathrm{ml}$. of $\Rightarrow$ $0.05 \mathrm{M}$. acetylcholine bromide to $0.05 \mathrm{ml}$. of serum. It was therefore decided to use a mixture of $0.05 \mathrm{ml}$. of serum and $0.05 \mathrm{ml}$. of $0.05 \mathrm{M}$. substrate for the test.

LINEARITY OF THE RATE OF $p$ H FALL UNDER THE CON-§ึ DITIONS OF THE TEST Clotted blood from 10 hos- $\overrightarrow{0}$ pital patients was centrifuged within one hour of collection and the serum separated. Each specimen $\vec{\omega}$ was equilibrated with $4 \% \mathrm{CO}_{2}$, mixed with substrate? and drawn into the capillary of the electrode. Theo fall of $p \mathrm{H}$ was then plotted against time. Figure $1 \vec{\infty}$ shows five of the curves produced all of which were nearly linear between $p \mathrm{H} \mathrm{7 \cdot 3}$ and 7.1.

ALKALINE HYDROLYSIS OF ACETYLCHOLINE BROMIDEO The capillary of the Astrup equipment was wellwashed with buffer and water. It was then filled $气$ with $1 \times 10^{-3} \mathrm{M}$. dibucaine hydrochloride solution for three minutes to inhibit the cholinesterase $\overrightarrow{0}$ present in any traces of serum on the capillary walls. The capillary was again washed with buffer followedo

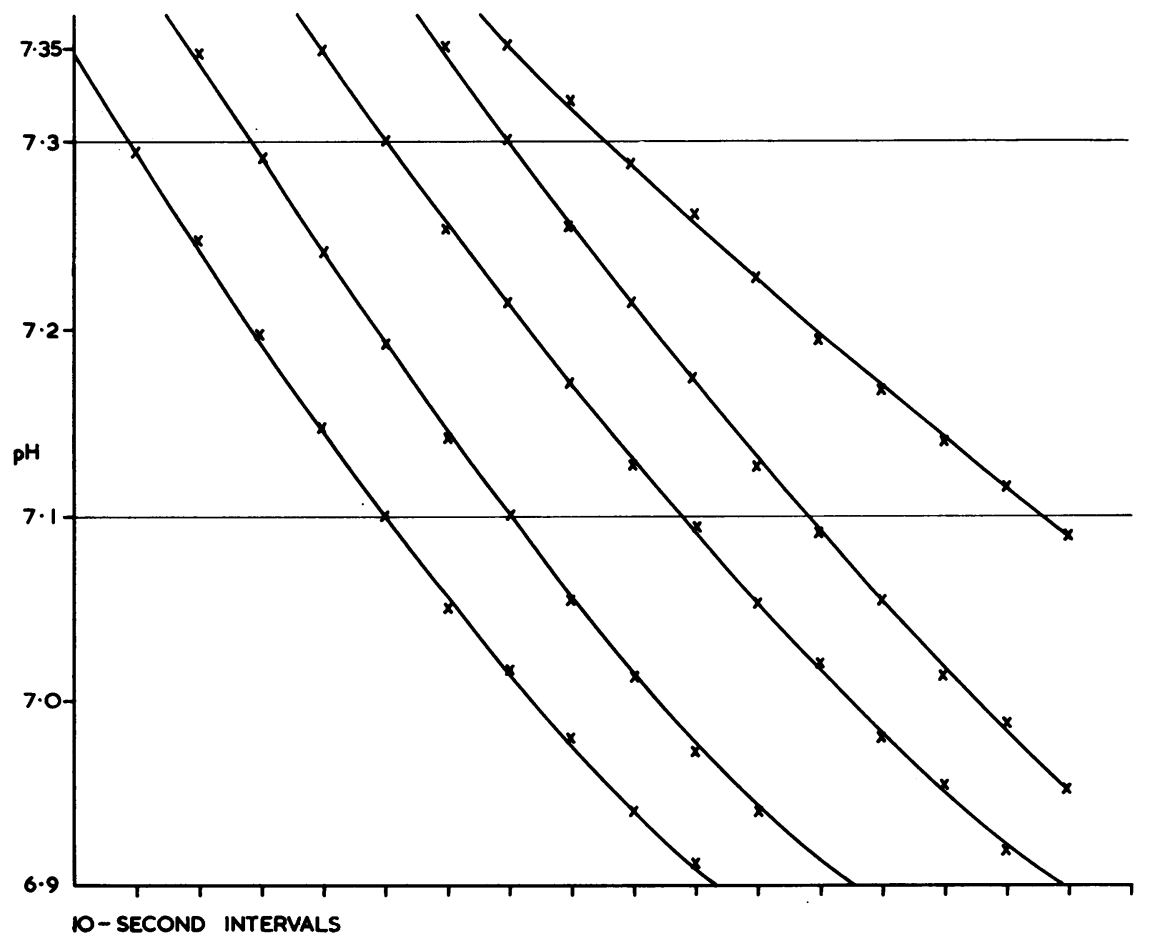

FIG. 1. Equal volumes of serum and $0.05 \mathrm{M}$. acetylcholine bromide incubated in the capillary af the Astrup microo equipment. Rates of fall of $\mathrm{pH}$ shown to be nearly linear between $7 \cdot 3$ and $7 \cdot 1$. 
by water, and filled with a mixture of equal parts $p \mathrm{H}$ 7.38 buffer solution and $0.05 \mathrm{M}$. acetylcholine bromide. No fall of $p \mathrm{H}$ was observed in $\mathbf{3 0}$ minutes, showing that alkaline hydrolysis of the substrate does not occur under these conditions.

CALIBRATION OF THE METHOD IN INTERNATIONAL UNITS An international unit of enzyme activity is defined as 'that which will catalyse the transformation of one micro mole of substrate under defined conditions' (International Union of Biochemists Commission on Enzymes, 1961).

As the fall of $p \mathrm{H}$ in the test is measured in a closed system, without exposure to the atmosphere, the calibration had to be performed under the same conditions. The cholinesterase present in $12 \mathrm{ml}$. of pooled serum from 10 blood donors was inhibited with $0.05 \mathrm{ml}$. neostigmine $(2.5 \mathrm{mg} . / \mathrm{ml}$.). Twenty minutes later, the cholinesterase activity was measured and the fall of $p \mathrm{H}$ found to be less than $0.01 \mathrm{pH}$ units in three minutes. The serum was next equilibrated with $4 \% \mathrm{CO}_{2}$ at $38^{\circ} \mathrm{C}$. for 90 minutes in a swirling tonometer. It was then anaerobically transferred to a $10 \mathrm{ml}$. syringe which was sealed until the next stage of the procedure.

Mixtures of $0.05 \mathrm{M}$. acetylcholine bromide and a solution containing $0.05 \mathrm{M}$. acetic acid and $0.05 \mathrm{M}$. choline bromide were prepared. The dead space in a well-lubricated, glass, $2 \mathrm{ml}$. syringe and needle was filled with clean mercury. The needle of the $2 \mathrm{ml}$. syringe was introduced into a rubber tube on the end of the syringe containing the equilibrated serum and the plunger drawn up to the $1 \mathrm{ml}$. mark. The needle was then withdrawn, dipped into the substrate-acidcholine mixture and the plunger drawn up to the $2 \mathrm{ml}$. mark. A further spot of mercury was then drawn into the syringe to wash the mixture from the dead space. The syringe now contained $1 \mathrm{ml}$. serum, $1 \mathrm{ml}$. substrate mixture, and a drop of mercury. The contents were mixed by shaking, the mercury expelled from the dead space, and the $p H$ measured on a sample sucked into the capillary of the electrode.

The results of this experiment, which was repeated on three different batches of pooled serum, are shown in Fig. 2 where the fall of $p H$ is related to the changes in the concentration of acetic acid in the mixtures. The mean of the three results show a fall of $p \mathrm{H}$ from $7 \cdot 3$ to $7 \cdot 1$ to be due to $2 \cdot 503 \mu$ moles of acetic acid.

When equal volumes of serum and $0.05 \mathrm{M}$. substrate were mixed in a closed system, therefore, a fall of $p \mathrm{H}$ from $7 \cdot 3$ to $7 \cdot 1$ may be said to have been due to the hydrolysis of $2.503 \mu$ moles of substrate. This, divided by the time taken in minutes for the fall, gave the enzyme activity in international

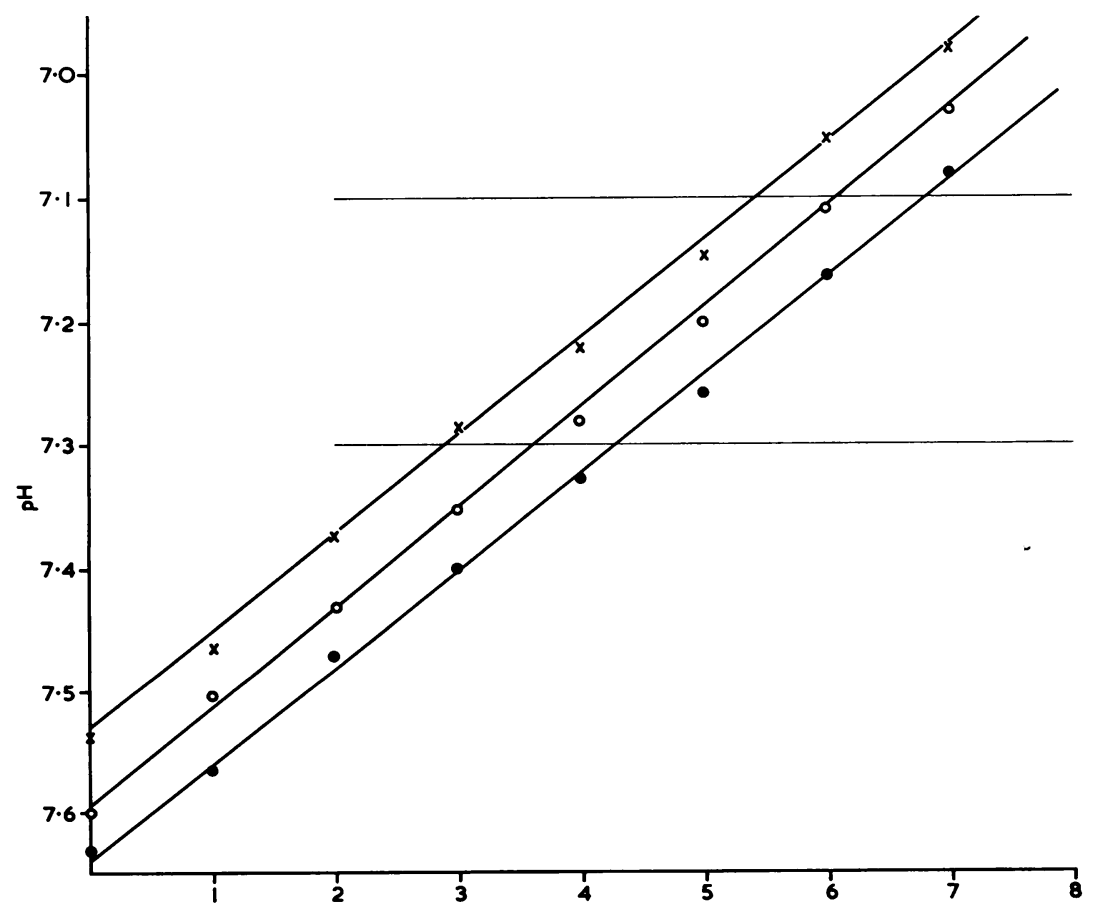

FIG. 2. Equilibration in international units. The pH was obtained by adding mixtures of $0.05 \mathrm{M}$ acetylcholine bromide, acetic acid, and choline bromide to an equal volume of serum in a closed system.

ACETIC ACID ( $\mu$ moles IN MIXTURE) 


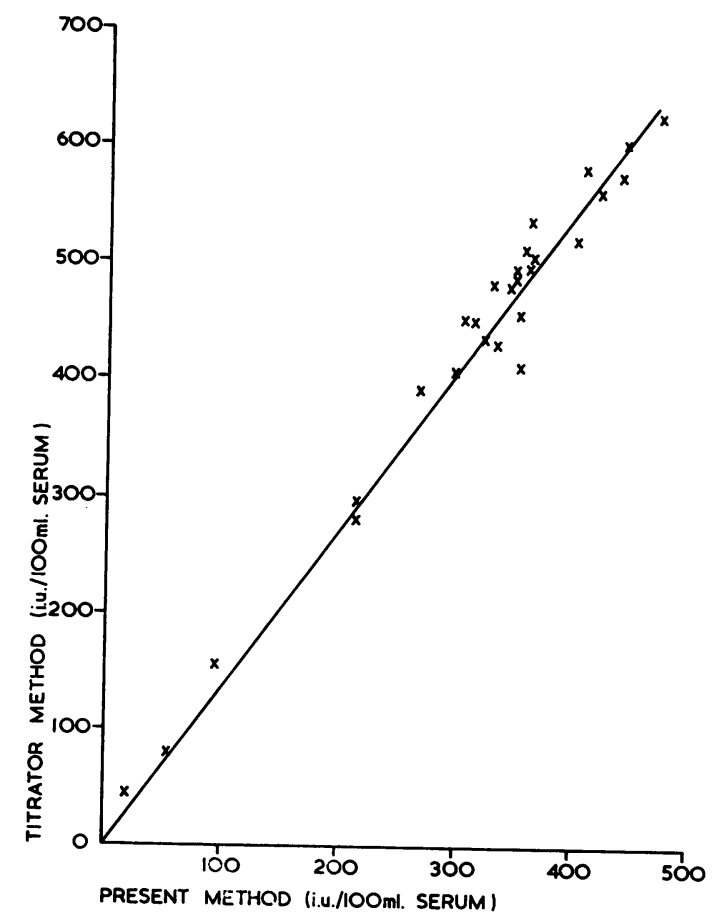

FIG. 3. Comparison between results by the present method and Radiometer titrator method. Regression coefficient $=0.74 .95 \%$ confidence limits 0.63 to 0.85 .

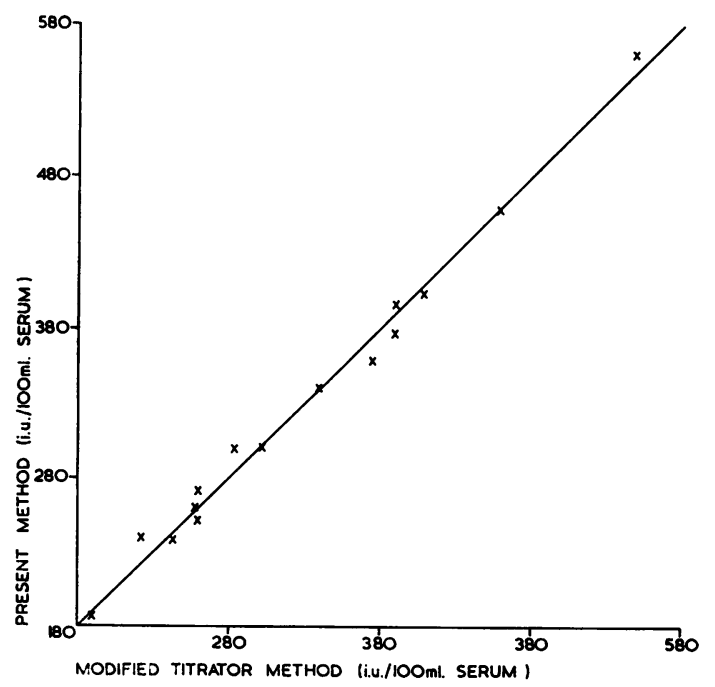

FIG. 4. Comparison between results by the present method and a modified titrator method using the same concentration of reagents in each case. The line with a slope of $45^{\circ}$ is not a calculated regression line. units per millilitre serum. If the time is measured seconds, then $\frac{2 \cdot 503}{t} \times 60=\frac{150}{t}=$ enzyme activiti in international units per millilitre serum.

\section{COMPARISON WITH A CONVENTIONAL METHOD}

Means of duplicate determinations of the activitie of 26 sera obtained by the new method were now compared with those obtained using a conventionat titration technique (Radiometer instruction leaflet) In this method a mixture of $25 \mathrm{ml}$. of saline, $1 \mathrm{ml}$. of serum, and $2 \mathrm{ml}$. of $10 \%$ acetylcholine bromide were incubated at $38^{\circ} \mathrm{C}$. in contact with the electrodes of $\mathrm{a}$ $p \mathrm{H}$ meter. The apparatus could be adjusted so thato $\mathrm{N} / 10$ sodium hydroxide was automatically added from a micrometer syringe burette to neutralize the acid produced and maintain the $p \mathrm{H}$ at $7 \cdot 4$. Figure shows that the results obtained by the new method are about $74 \%$ of those obtained by the titrator technique.

It was considered that the difference in results was. probably due to using a 1 in 2 dilution of serum in the new method compared with 1 in 28 in the titrato method. A further 15 samples were thereforg compared. In this case the titrator method was modified. Equal volumes of serum and $0.05 \mathrm{M}$ acetylcholine bromide were used as the incubation mixture and the $p \mathrm{H}$ was maintained at 7.2 with scdium hydroxide. These conditions simulated thoset used in the micro method and the results obtained by both methods are seen to agree closely (Fig. 4).

The 'international units' obtained by the new method are not the same as those by other methods because, though each of them measures the numbe? of micro moles of substrate transformed eacli minute, the conditions of the test differ in all casesIt is important, therefore, to give the normal range when expressing results.

\section{RELATIONSHIP BETWEEN THE ENZYME CONCENTRATION AND ACTIVITY AS MEASURED BY THIS METHOD}

A patient who developed scoline apnoea was founc to have a cholinesterase activity of less than 20 i.u.w per $100 \mathrm{ml}$. serum. A series of mixtures of this serune was made with serum having a normal cholinesterase activity. The activities of the mixtures were then measured. The calculated values (all very low) due to the abnormal serum were then subtracted from the 0 total activity. The test was repeated using different? specimens of the patient's and normal serum (Figs? 5 and 6). These results show that the activity aso measured by this method is proportional to the concentration of the enzyme. 

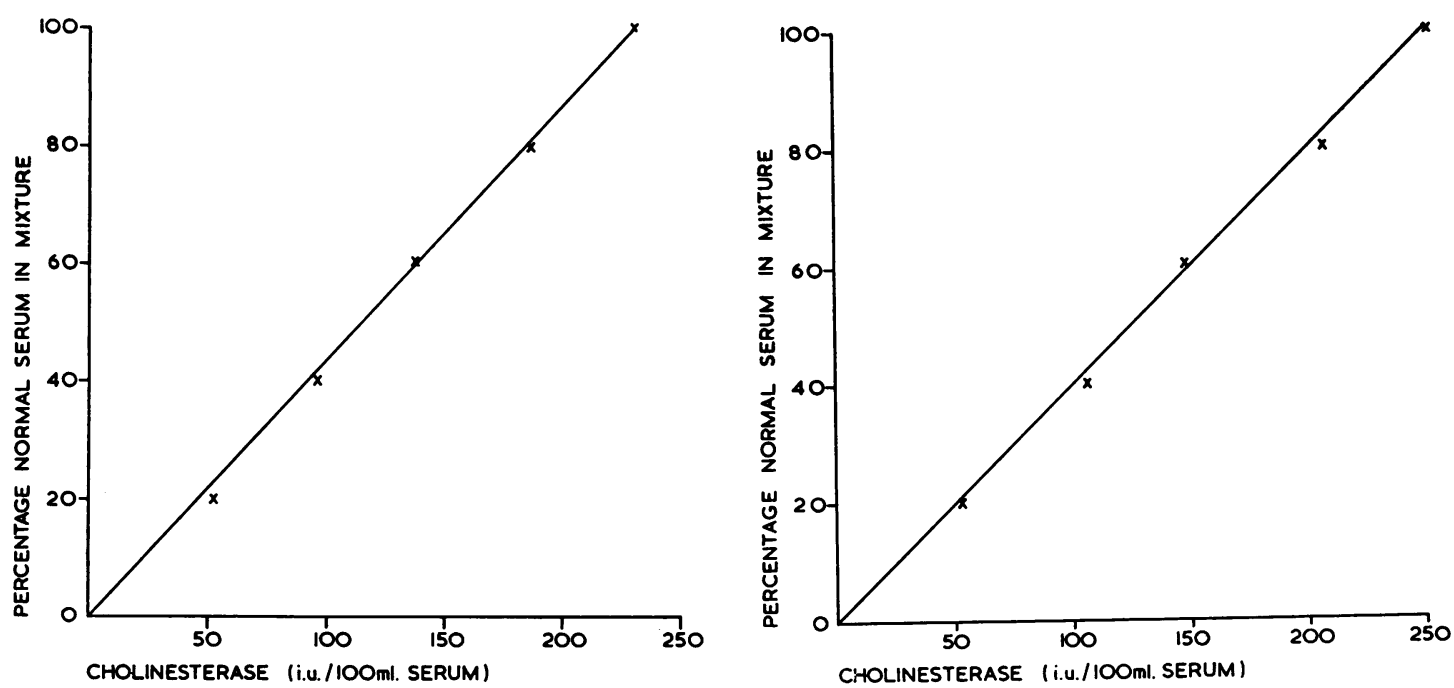

FIGS. 5 and 6. Enzyme activity related to the concentration of normal serum in a mixture of sera with normal and very low cholinesterase activities.

\section{KEEPING PROPERTIES OF THE SERUM ENZYME}

There was no change in the enzyme activity when serum was stored at $25^{\circ} \mathrm{C}$. and $37^{\circ} \mathrm{C}$. for 48 hours and for three months at $-20^{\circ} \mathrm{C}$.
RESULTS OBTAINED BY THE METHOD

In Table I the serum cholinesterase activities of patients are listed along with the dibucaine and fluoride numbers and the reason for performing the

TABLE I

SERUM CHOLINESTERASE ACTIVITIES OF PATIENTS IN PRESENT SERIES

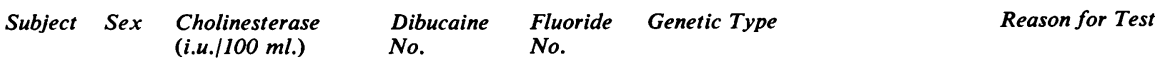

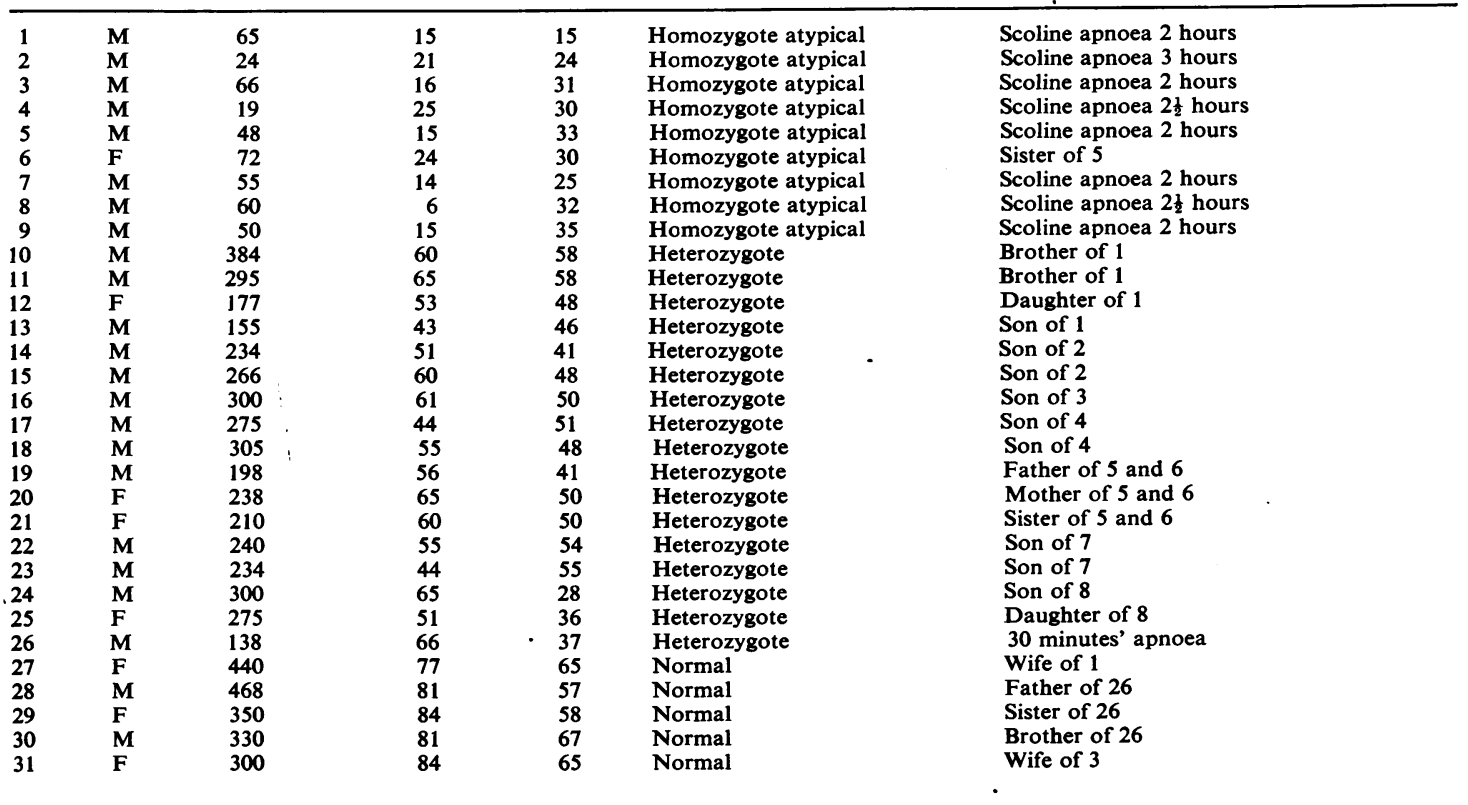


test. Dibucaine and fluoride numbers were measured using the Gilford attachment to a Unicam SP 500 monochromator unit.

It should be noted that anticholinesterase drugs are sometimes given to patients before the cause of the apnoea is found. In these cases the cholinesterase activity will be found to be low and the dibucaine and fluoride numbers incorrect, due to the presence of the previously administered inhibitor.

The method may also be used as a screening test for poisoning by organic phosphorus compounds used as insecticides (Aldridge and Davies, 1952) or as long-acting pupil dilators in the treatment of glaucoma. Dibucaine and fluoride numbers on these patients may also be incorrect due to the circulating inhibitor.

\section{DISCUSSION}

The most useful application of this method is the investigation of prolonged apnoea during and after anaesthesia. This may be due to slow hydrolysis of the scoline (succinyl dicholine) used as a muscle relaxant for intubation. The scoline is usually rapidly hydrolysed by serum cholinesterase so that relaxation only lasts about three minutes. If there is a very low concentration of the enzyme or the presence of an atypical enzyme which, while able to hydrolyse acetylcholine has little effect on the scoline, there will be prolonged relaxation with consequent apnoea (Bush 1961; Lehmann, Liddell, Blackwell, O'Connor, and Daws, 1963).

The homozygotes for the atypical enzyme have a very low serum cholinesterase activity which may be rapidly discovered by this technique as the Astrup apparatus is generally in readiness for $p \mathrm{H}$ measurement throughout the day. Blood may be taken by venepuncture or by heel or thumb prick into capillary tubes without anticoagulant. While it is being centrifuged to separate the serum a tube of $0.05 \mathrm{M}$. acetylcholine bromide may be thawed. The enzyme activity is measured and the result available in less than 10 minutes. We have investigated eight patients with apnoea of longer than 30 minutes' duration following scoline. All had values below 75 i.u. $/ 100 \mathrm{ml}$. serum.
Heterozygotes for the normal and atypica enzymes occasionally develop apnoea following scoline (Tefler, MacDonald, and Dinwoodie, 1964. and may have a normal or only slightly reduced cholinesterase activity. These should be investigated by the measurement of the dibucaine and fluoride. numbers (Kalow and Genest, 1957; Lehmann et $a \vec{P}_{\overparen{\Phi}}$ 1963).

The principal disadvantage of the method is that is only accurate when used for serum which has $\vec{\Phi}$ reasonably normal standard bicarbonate since no buffer solution is used. Red cells and tissue extractos have different buffering capacities from plasma an a calibration curve would need to be performed in each case. Theoretical disadvantages are that the initial rate of enzyme activity is not measured and that the fall of $p \mathrm{H}$ will inhibit the enzyme. Afterw equilibration with $4 \% \mathrm{CO}_{2}$ the fall to $7 \cdot 3$ from the time the substrate is added usually only takes a few seconds. The fall of $p \mathrm{H}$ is only over $0.2 p \mathrm{H}$ units and it has been shown that the time taken for this fall proportional to enzyme concentration.

As acetylcholinesterase in red cells will alsŏ hydrolyse the substrate there may be some interference from this enzyme if there is any haemolysio or if the serum is left in contact with the clot for long time.

The method is only possible because of the extreme stability and sensitivity of the $p \mathrm{H}$ equipmen? Any equally stable apparatus may of course be use in place of the A.M.E. 1. The principle may well be used for the investigation of other enzyme-substrate systems which result in a change of $p \mathrm{H}$.

\section{REFERENCES}

Aldridge, W. N., and Davies, D. R. (1952). Brit. med.J., 1, 945. Bush, G. H. (1961). Brit. J. Anaesth., 33, 454.

Harris, H., and Robson, E. B. (1963). Lancet, 2, 218.

International Union of Biochemistry. Report of the Commission of Enzymes. (1961). New York, Pergamon Press.

Kalow, W., and Genest, K. (1957). Canad. J. Biochem., 35, 339.

Lehmann, H., Liddell, J., Blackwell, B., O'Connor, D. C., and Daw? A. V. (1963). Brit. med. J., 1, 1116.

Rider, J. A., Hodges, J. L. Jr., Swader, J., and Wiggins, A. D. (1957心 J. Lab. clin. Med., 50, 376.

Tefler, A. B. M., MacDonald, D. J. F., and Dinwoodie, A. J. (1964 NO Brit. med. J., 1, 153. 